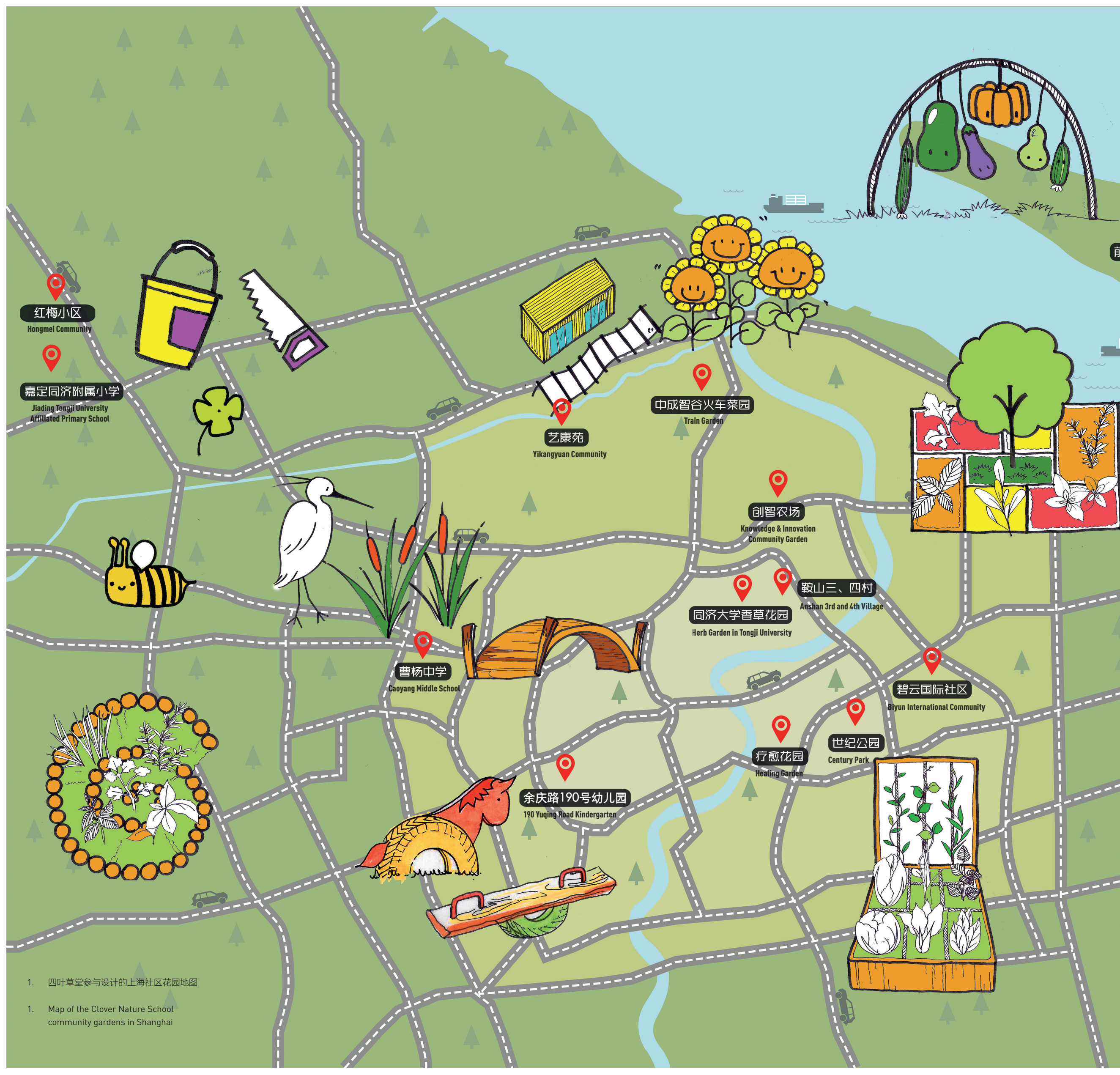




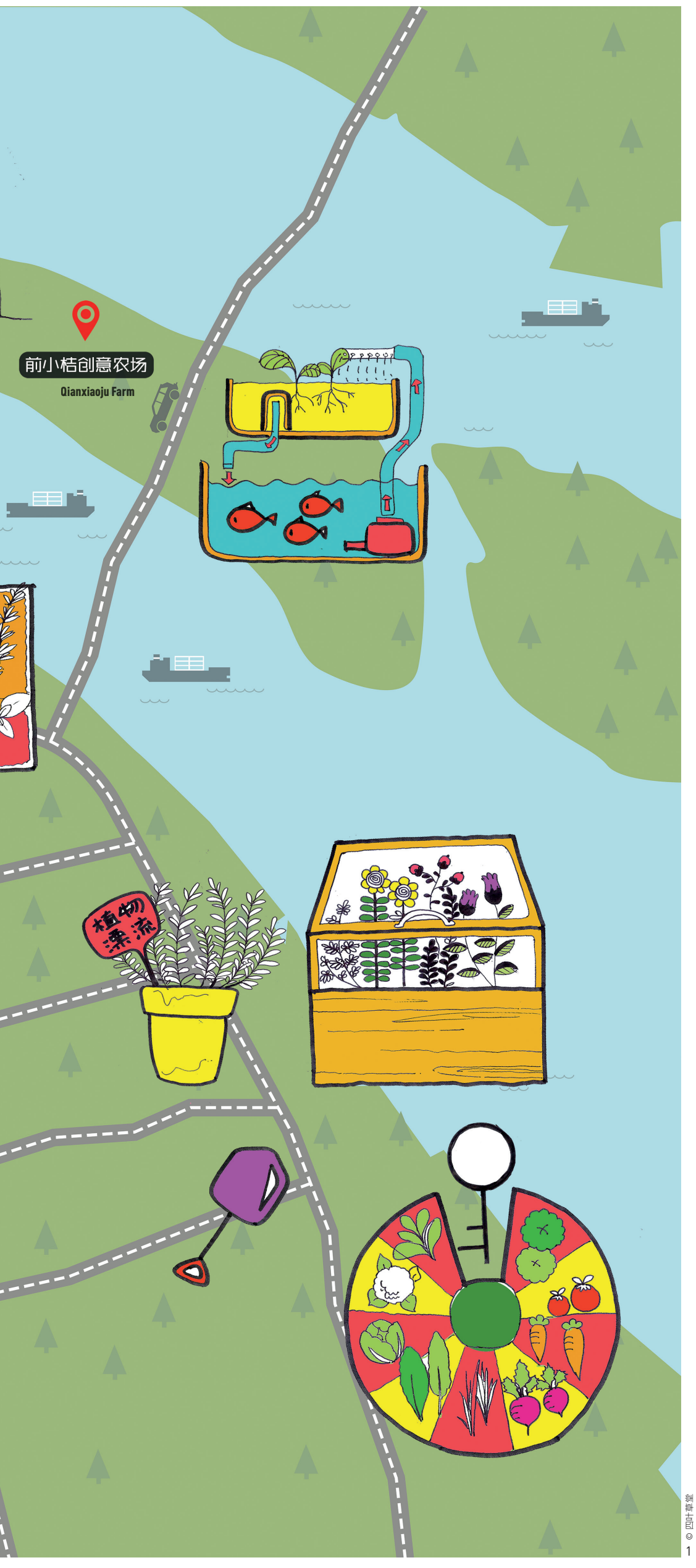

\section{从可食景观到活力社区 四叶草堂上海社区花园系列实践 FROM EDIBLE LANDSCAPE TO VITAL COMMUNITIES: CLOVER NATURE SCHOOL COMMUNITY GARDENS IN SHANGHAI}

刘悦来, 范浩阳, 魏闽, 尹科娈, 严建雯

/ Yuelai LIU, Haoyang FAN, Min WEI, Keluan YIN, Jianwen YAN

\begin{abstract}
社区花园是一种起源于欧美国家的绿 地组成形式。它是当地社区民众在都市获取 食物的来源之一, 也是民众参与城市绿地管 理维护的途径之一, 更是社区营造的“抓 手”。社区花园一般位于住区、园区、街 区和校区等地, 其规模可大可小。景观的 可食性和民众的参与性是社区花园的重要 特点。

在中国的高密度城市中, 由于土地稀 缺, 加之社区花园的不便管控性, 社区花园 一直没有得到广泛推广。但2010年以来, 在以上海为代表的高密度城市的中心城区, 开放绿地空间的增量已近乎为零。如何在这 样的背景下提高城市居民福祉, 社区空间和 城市隙地就成为优化存量绿地空间品质的前 沿阵地。自2014年以来, 上海四叶草堂青 少年自然体验服务中心 ( 以下简称 “四叶草 堂”）在上海中心城区陆续建成了多个不同 类型的社区花园, 本文将以这些社区花园实 践为例, 探讨公共参与及可食景观营造的可 能性和方向。
\end{abstract}

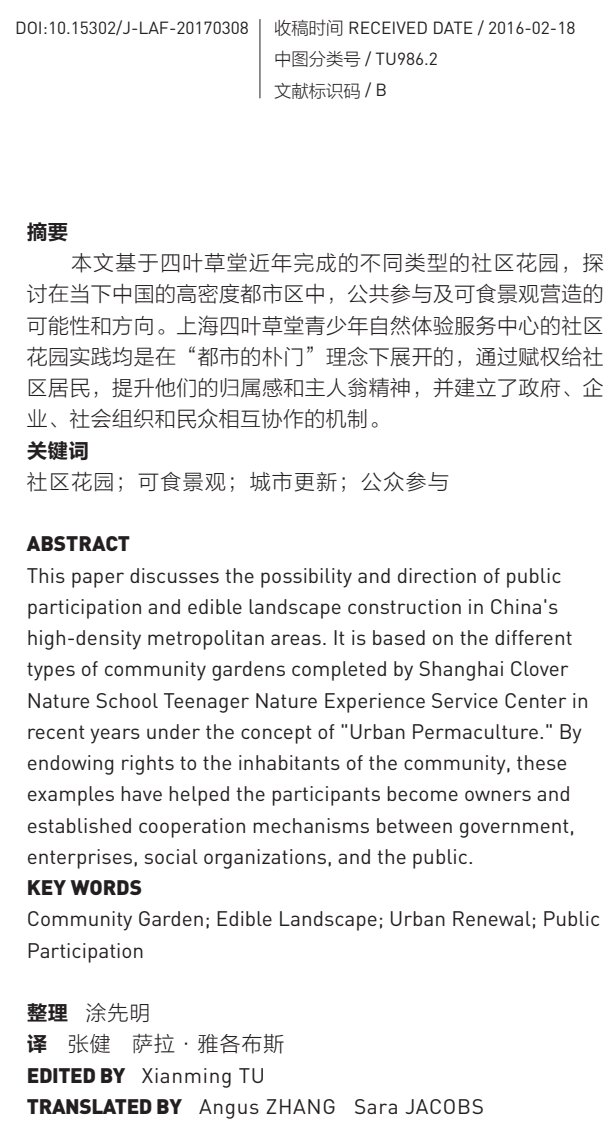
讨在当下中国的高密度都市区中, 公共参与及可食景观营造的 可能性和方向。上海四叶草堂青少年自然体验服务中心的社区 花园实践均是在 “都市的朴门”理念下展开的，通过赋权给社 区居民，提升他们的归属感和主人翁精神，并建立了政府、企 业、社会组织和民众相互协作的机制。

关键词

社区花园; 可食景观; 城市更新; 公众参与

ABSTRACT

This paper discusses the possibility and direction of public participation and edible landscape construction in China's high-density metropolitan areas. It is based on the different types of community gardens completed by Shanghai Clover Nature School Teenager Nature Experience Service Center in recent years under the concept of "Urban Permaculture." By endowing rights to the inhabitants of the community, these examples have helped the participants become owners and established cooperation mechanisms between government, enterprises, social organizations, and the public. KEY WORDS

Community Garden; Edible Landscape; Urban Renewal; Public Participation

整理 涂先明

译 张健 萨拉·雅各布斯

EDITED BY Xianming TU

TRANSLATED BY Angus ZHANG Sara JACOBS 


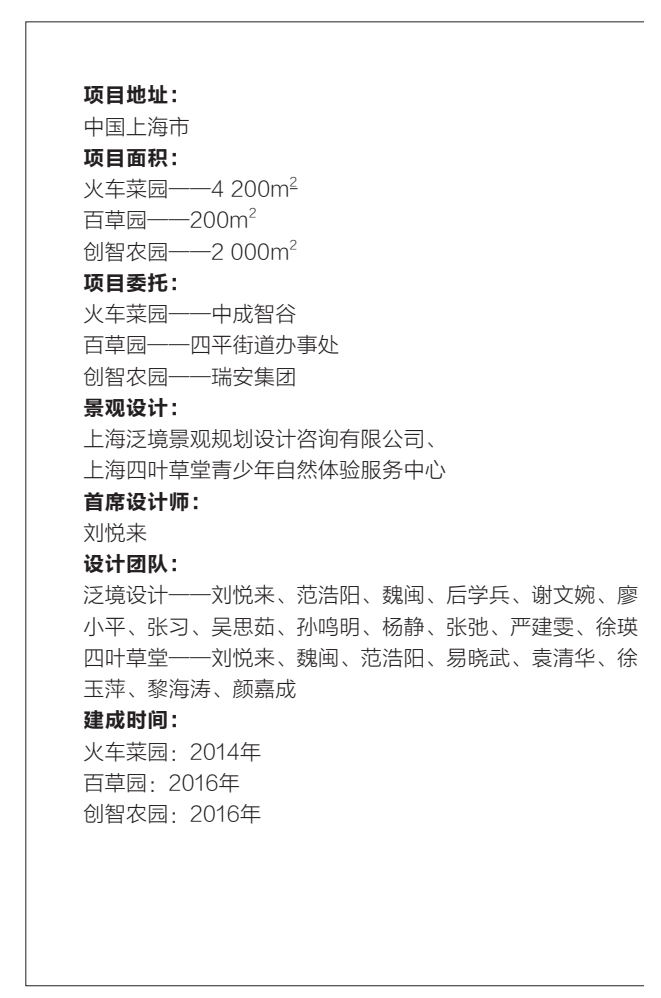

\section{都市的朴门：火车菜园}

朴门永续设计 (Permaculture) 取自 permanent (永恒) 和agriculture (农业) 这两个单词, 最早是由比尔 - 墨利森和戴 维・洪葛兰于1974年共同提出的一种生态设 计方法 ${ }^{[1]}$ 。这一理念最初是指可持续性的食物 生产方式，如今已拓展成一个涵盖性更广的 文化理念，其核心价值为 “照顾人类、照顾 地球、分享盈余”。朴门永续设计致力于营 造多样性丰富的、整合的、自给自足的生态 系统 ${ }^{[2]}$ 。

四叶草堂的社区花园实践均是在“都市 的朴门”理念下展开的, 旨在探索城市微空 间的自然保育及社会参与方式，期待通过 朴门营造的途径在城市隙地中播种绿色， 连接城市与乡村, 使之形成一个有机的生产 共同体。

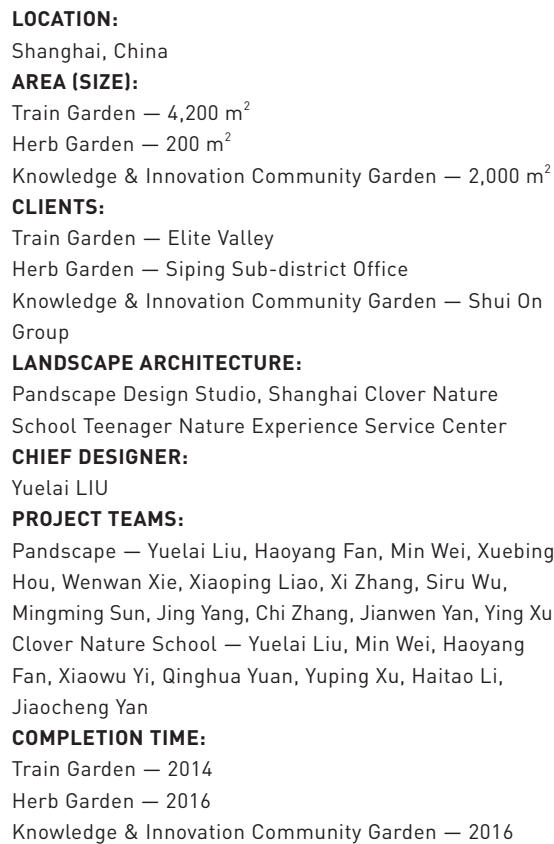

Pandscape - Yuelai Liu, Haoyang Fan, Min Wei, Xuebing Hou, Wenwan Xie, Xiaoping Liao, Xi Zhang, Siru Wu Mingming Sun, Jing Yang, Chi Zhang, Jianwen Yan, Ying Xu Clover Nature School - Yuelai Liu, Min Wei, Haoyang Fan, Xiaowu Yi, Qinghua Yuan, Yuping Xu, Haitao Li, Jiaocheng Yan COMPLETION TIME:

Train Garden - 2014

Herb Garden - 2016

Knowledge \& Innovation Community Garden - 2016

四叶草堂于2014年完成的火车菜园即为 一例。该场地位于上海市宝山区中成智谷创 意产业园区东侧, 占地面积约 $700 \mathrm{~m}^{2}$, 是一 处沿着老淞沪铁路的狭长区域。这里原为防 护绿地, 但因位置偏僻, 长期无人管理, 成 为了堆放建筑垃圾和居民自发种植蔬果的城 市边角地带。在朴门永续的设计理念之下, 我们根据场地活动的类型和使用频率，规划 了5个分区：香草菜园区、食物森林区、大 田作物区、林产作物区、自然保育区。通过 场地整理、植树造林、植被修复、雨水收集 净化、自然植被覆盖、农作物种植、生态堆 肥、蚯蚓塔等生态治理措施, 大大提高了这 片区域的土地生产力和生物多样性。

同时，我们在场地中辟出一处“一米园 圑”, 其由若干个一米见方的小菜园组成, 并由社区居民、白领等人士共同参与种植, 在生产蔬菜的同时，也为参与者创建了交流
的平台 ${ }^{[3]}$ 。火车菜园也成为中成智谷园区、周 边社区和学校集体举办自然教育活动的热门 场所。

\section{我们是社区的主人：百草园}

虽然依据《物权法》规定，小区绿化由 全体业主所有、共同维护。在国内, 社区绿 地通常都是以最低成本的投入托管给物业。 这样的结果往往是居民在不知道自己有哪些 权责的情况下, 就拱手将社区花园的管理权 交给了物业, “集体所有”也就成了“集体 没有”。品尤其在一些管理养护低下的老旧小 区中，常会发生社区中的公共空间被居民私 自圈占、当做“私有菜地”的现象。而化解 这些问题的解药即为社区营造, 这一过程也 促进了社区凝聚力的构建。

位于上海市杨浦区鞍山四村第三小区 


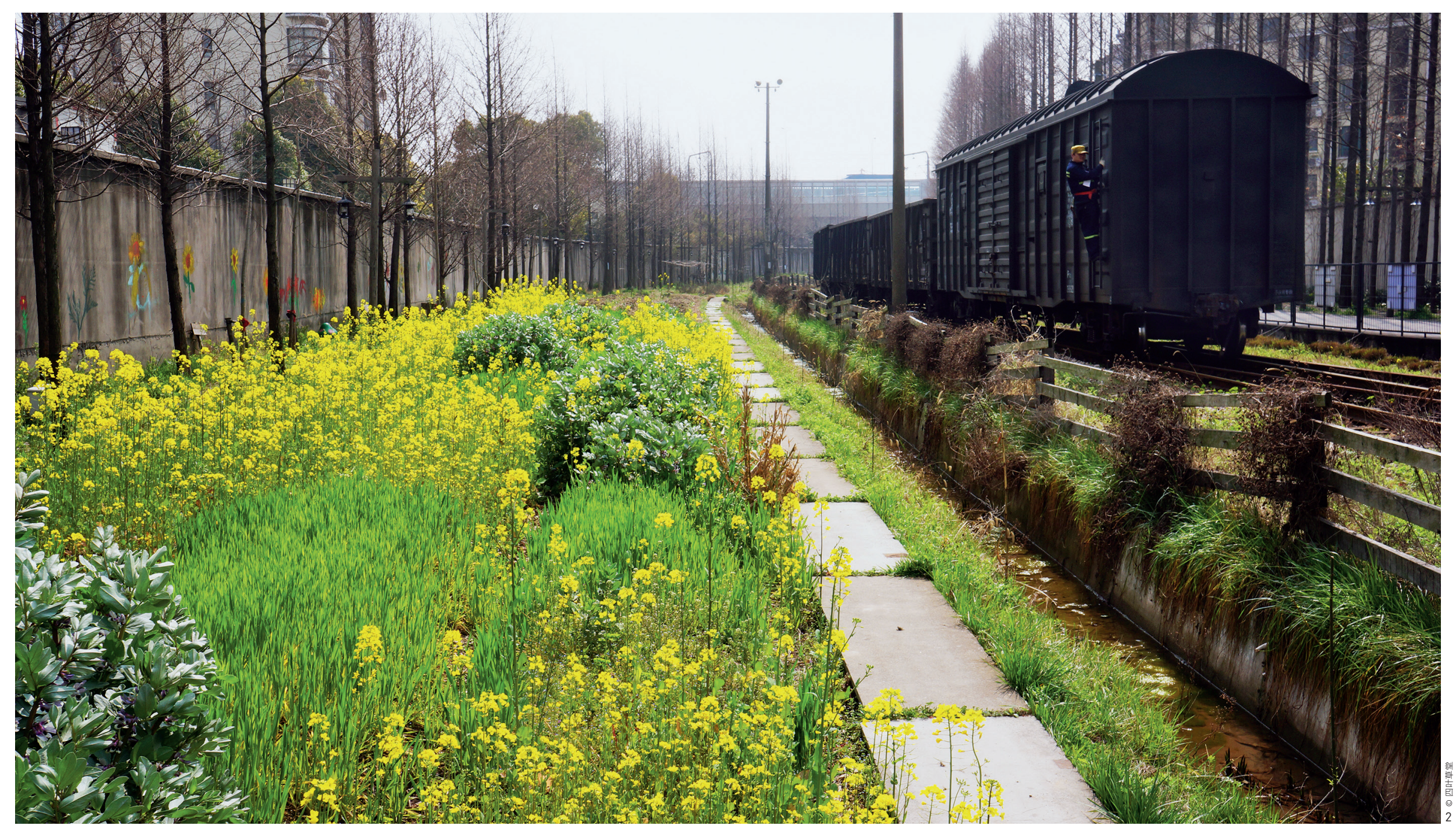

2. 火车菜园保留了原有 的火车头、轨道等历 史遗迹。

3. 经过数年的自然演 野趣的场地。

2. Disused locomotive and rail trail were reserved in Train Garden

3. It has evolved into a site full of wildness
over several years.
中心广场的百草园, 通过将老旧小区中单调 的中心绿地转化为居民的公共客厅, 以及开 展以植物为纽带的社交活动, 增进了邻里关 系。占地面积仅约 $200 \mathrm{~m}^{2}$ 的百草园为社区 居民提供了日常休息、亲子互动、自然教育 的场所, 属于小区内部居民自治的社区花园 典型。百草园主要包含儿童活动区、香草螺 旋花园区、花卉地被区和垃圾分类区等功能 分区。园中主要种植着花卉、香草和果树, 其中一些植物是居民自发贡献的。目前百草 园有“一老” “一小”两个自治兴趣小组: “一老” 是社区里的老年花友会, 他们在社 区中分享养护管理的心得体会, 并组织相关

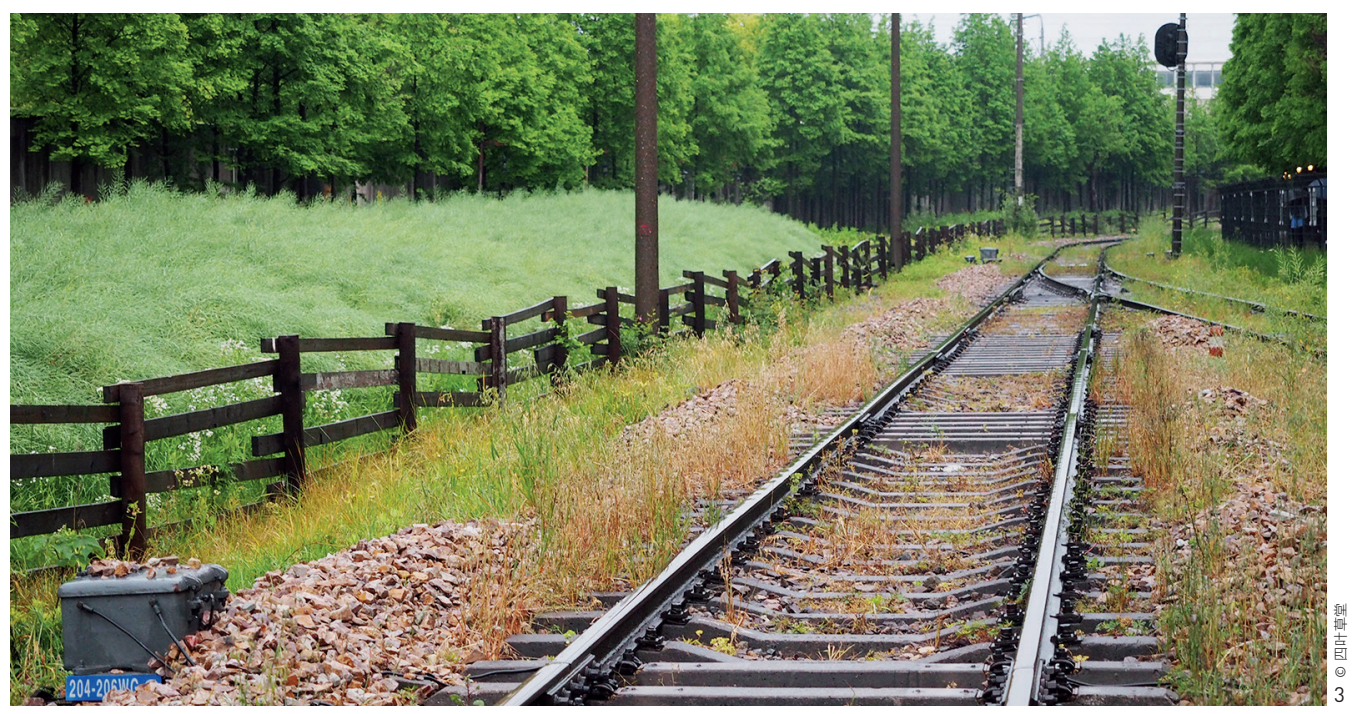



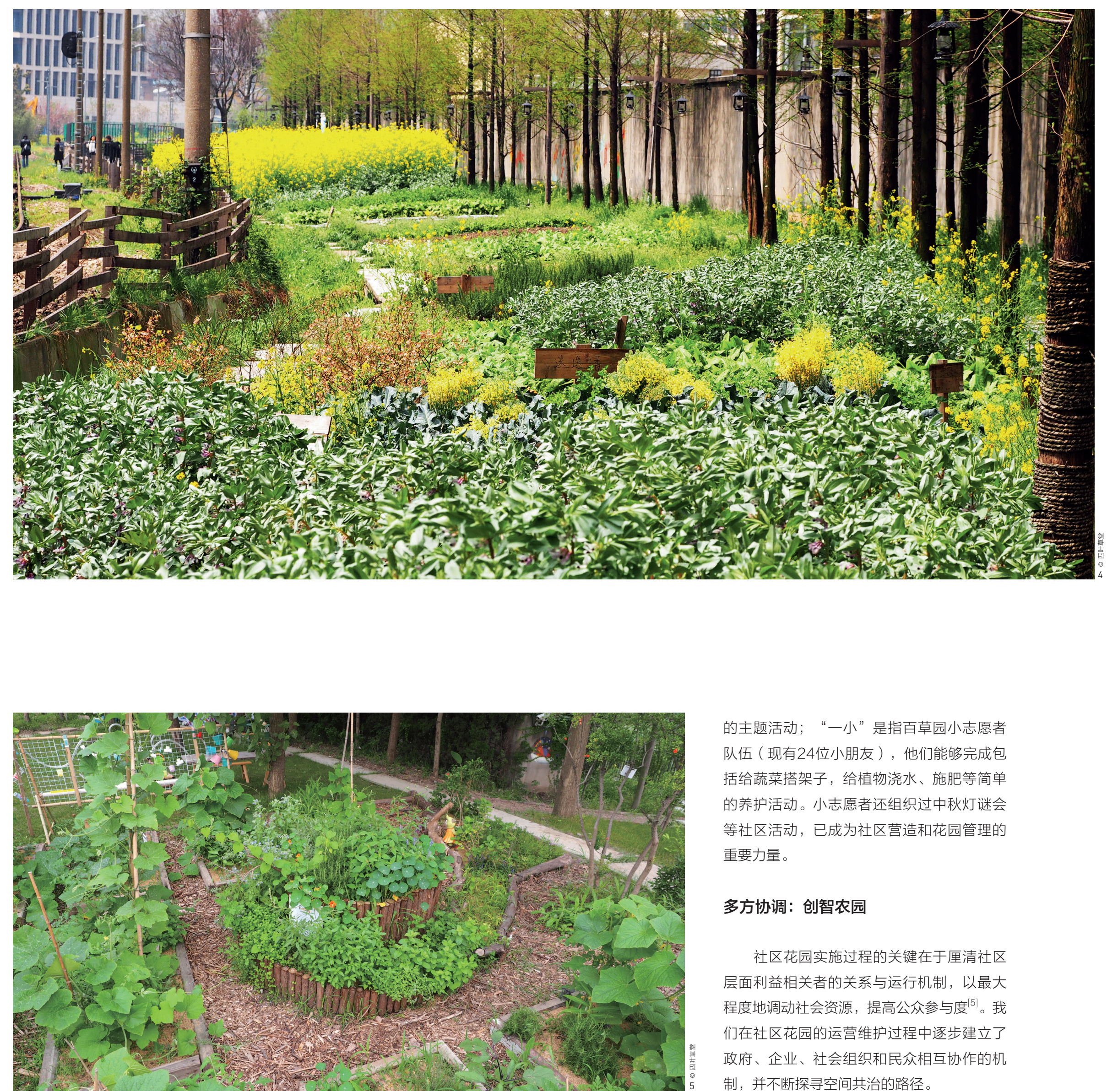

的主题活动; “一小” 是指百草园小志愿者 队伍（现有24位小朋友），他们能够完成包 括给蔬菜搭架子，给植物浇水、施肥等简单 的养护活动。小志愿者还组织过中秋灯谜会 等社区活动, 已成为社区营造和花园管理的 重要力量。

多方协调：创智农园

社区花园实施过程的关键在于厘清社区 层面利益相关者的关系与运行机制, 以最大 程度地调动社会资源, 提高公众参与度 ${ }^{[5]}$ 。我 们在社区花园的运营维护过程中逐步建立了 政府、企业、社会组织和民众相互协作的机 制，并不断探寻空间共治的路径。 
创智农园位于上海市五角场商圈中的 创智天地园区西侧, 四周是住宅区和产业园 区。这是一处占地面积约为 $2000 \mathrm{~m}^{2}$ 的街旁 绿地。因地下铺设有重要市政管线, 场地未 能得到充分利用。2016年杨浦科创集团和 瑞安集团决定对场地进行改造, 该项目由 瑞安集团代建代管，社会组织参与日常运 营, 成为了上海市首个建于开放街区中的社 区花园。

在创智农园的场地规划中, 我们将农园 分为移动建筑区、公共社交区、一米菜园区 和公共农事区。创智农园以打造自然学校 和社区营造策源地为设计目标，所有的设 计元素都服务于科普教育和公共参与, 包 括室内种子图书馆、DIY雨水收集系统、植物 科普标识系统、室内室外公共桌椅和可食用 植物等。

瑞安集团在创智农园项目中起到了关 键作用。从农园的策划设计到建设、运营和 维护，瑞安集团提供了主体经费，并保证空 间持续地开放共享，这也是企业社会责任的 直接体现。在管理层面，瑞安集团以社会公 开招募的形式, 聘请第三方社会组织进行管 理运营维护。社会组织四叶草堂负责运营维 护工作，包括专业技术、日常管理、活动策 划、运营组织等方面，是政府、企业、居民 三者间的桥梁。该项目所涉及的政府层面包 括区政府行政主管部门、街道办事处以及居 委会等。同时, 我们希冀社区力量在日后能 形成自组织的群众团体。

\section{社区花园网络：社区花园促进会}

为推动社区花园在上海的广泛开展, 2016年由一群有志于推动社区园艺与社区 营造的志愿者发起的上海社区花园促进会项 目 (简称SCGA) 开始试运行。SCGA旨 在多元有序地推进上海社区花园的发展, 致力于推进上海2040食物森林计划（简称 SFFP2040) 一一到2040年在上海建设 2040 处食物森林。

2017年1月，SCGA推出了上海社区花 园地图应用程序, 试图构建社区花园网络:
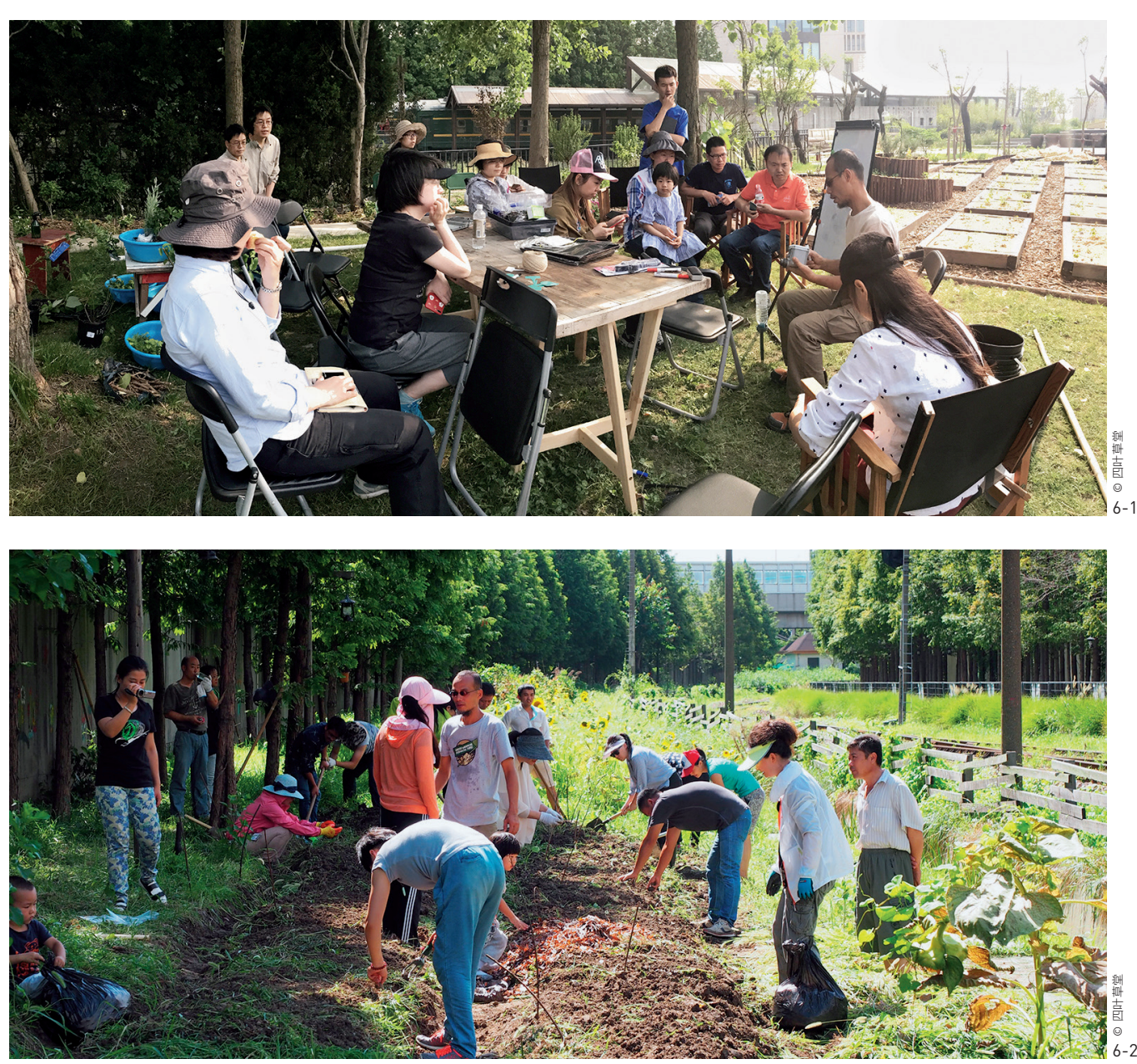

用户可以通过这一应用查看上海市各个社区 花园的分布并了解花园详情。而社区花园信 息库的构建, 也通过众包的方式由公众参与 提供。SCGA平台还会实时更新社区花园的 最新活动预告, 用户可以了解活动详情, 并 且报名参加。

\section{结语}

不同类型的社区花园均以社区绿色空间 为载体, 以公众参与为主要力量, 旨在调动 社会各层面的积极因素参与社会公共事务。 我们期待在未来的城市中能够出现更多不同 实践方式的社区花园。LAF

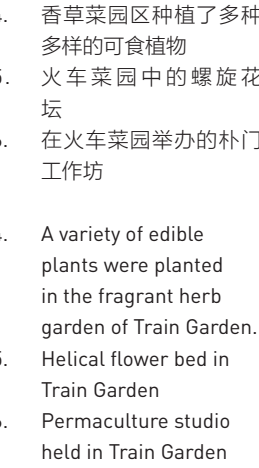


The Community Garden model originated in Europe and the United States.

Community gardens are a way for the local community to obtain food in the city, be involved in the management and maintenance of urban green spaces, and contribute to community development. In community gardens, edible landscaping is both horticultural and shared by the community. Edible landscaping and public participation are the most important features of community gardens, and they can be located in places as diverse as residential areas, parks, and schools. In China's high-density cities, there has been little community garden development due to the scarcity of land and the difficulty of community garden management. In high-density cities such as Shanghai, new green open space is approaching zero in 2010. In order to improve the wellbeing of citizens, the community spaces and urban fragmented spaces have been identified for improvement. Since 2014, Shanghai Clover Nature School Teenager Nature Experience Service Center (hereinafter referred to as Clover Nature Schooll has been building many different types of community gardens in downtown Shanghai. This article explores the possibility and direction of public participation and edible landscaping through these community gardens.

\section{Urban Permaculture: Train Garden}

Permaculture - a system of design principles that would be both permanent and agricultural - was first proposed as an ecological design method by Bill Mollison and David Holmgren in $1974^{[1]}$. Initially this concept focused on sustainable modes of food production, but it has evolved into a broader cultural concept with the core value of "taking care of people, taking care of the planet and sharing the surplus." Permaculture is committed to creating rich, diverse, integrated, and self-sufficient ecosystems ${ }^{[2]}$.

Clover Nature School's community gardens have been carried out as examples of urban permaculture through both natural conservation and social participation in urban micro-spaces. These gardens use urban fragmented spaces to create organic production communities between the city and the village.

One example, the Train Garden, was completed in 2014 in the Baoshan District of Shanghai. The garden covers 700 square
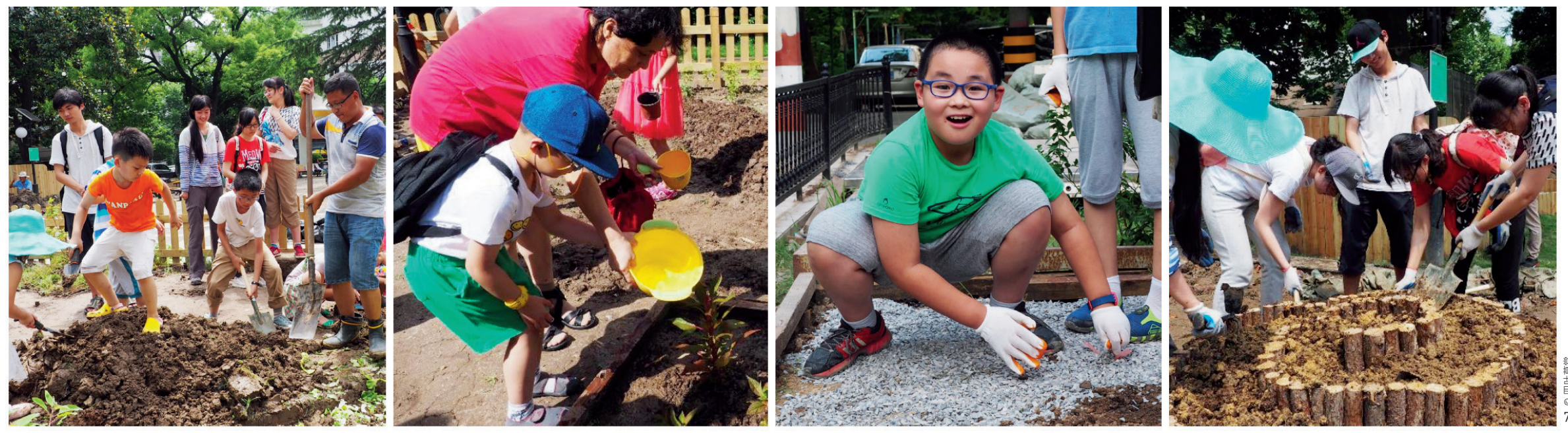

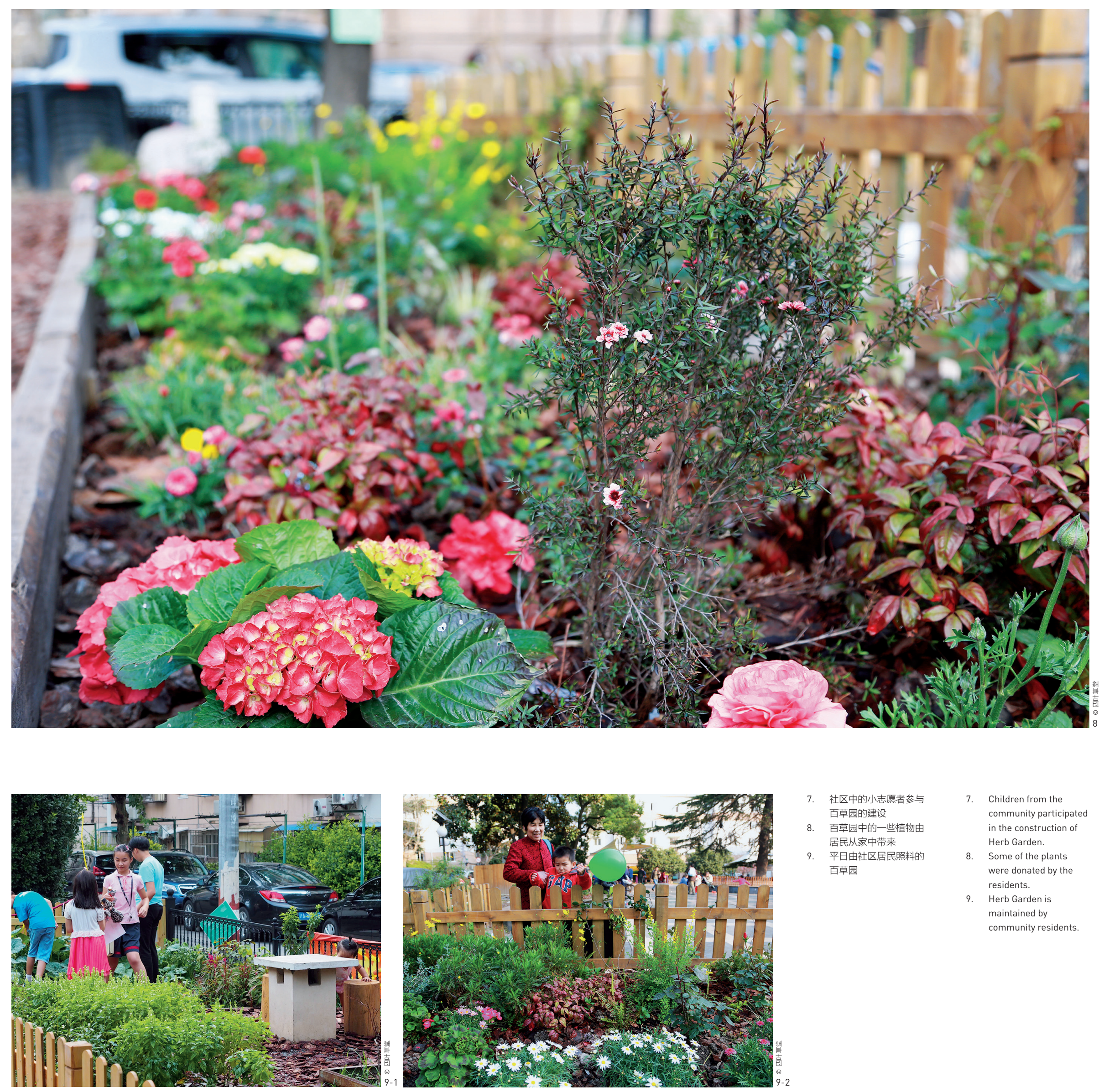

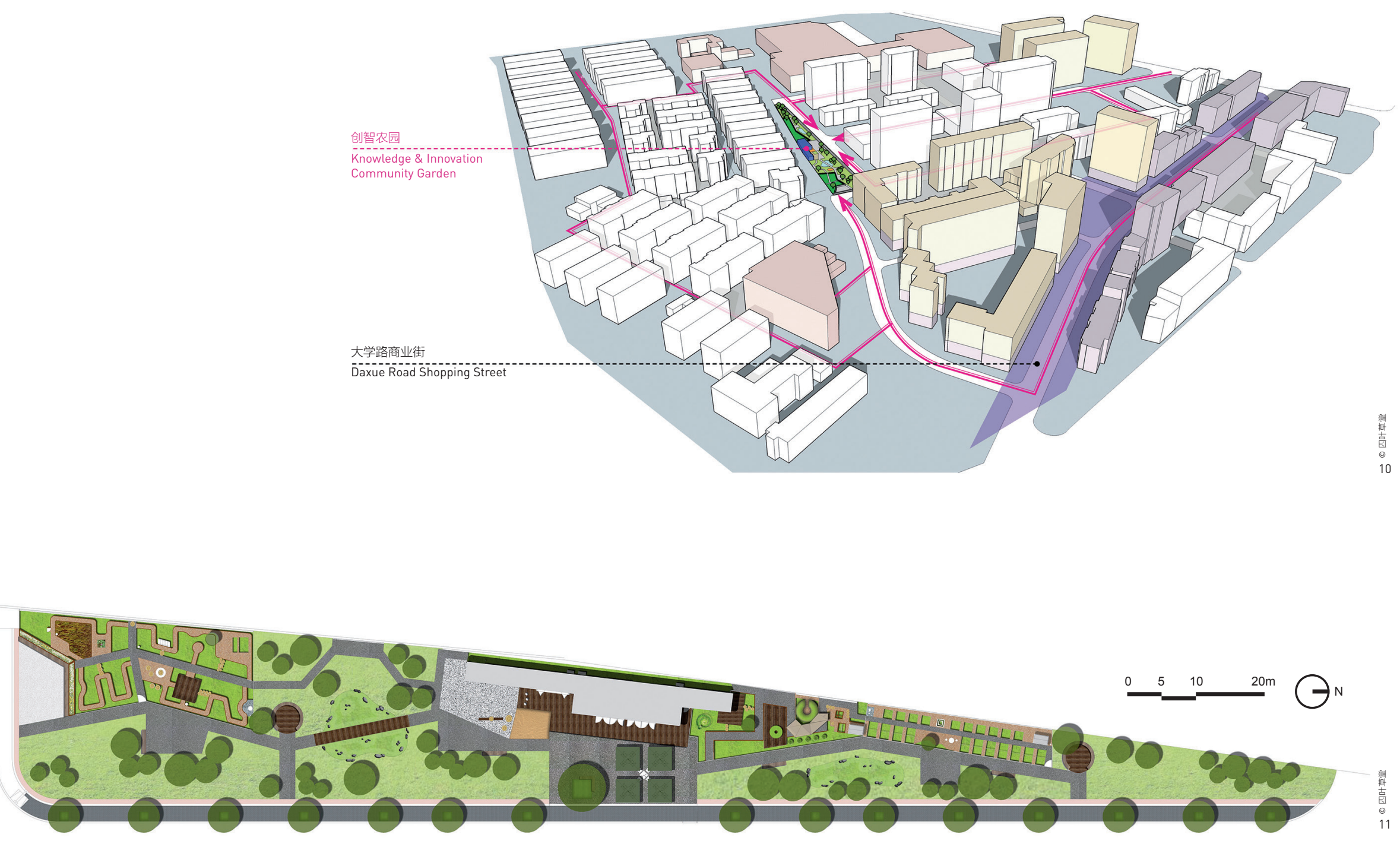

meters in the east of the creative industry cluster area known as the Elite Valley. The narrow area was originally a green buffer along the old Shanghai-Wusong Railway, and due to its remote location and neglect, it became a dump for both construction waste and the residents' vegetable gardens. Using permaculture design principles, we divided the site into five sub-districts according to activities and frequency of use. These included an fragrant herb garden, food forest, crop field, productive forest, and natural conservation area. Through ecological management such as site finishing, afforestation, vegetation restoration, rainwater harvesting and purification, natural vegetation cover, crop cultivation, ecological composting and worm tower, land productivity and species have been greatly improved.

Additionally, we set up a number of pocket gardens on the site to be cultivated and maintained by nearby community residents and office workers. These spaces produced vegetables while creating a communication platform for the public ${ }^{[3]}$. The Train Garden has become a popular site for outdoor education organized by the surrounding communities and schools.

\section{We Are the Community: Herb Garden}

China's Property Law stipulates that green areas are owned and maintained by all the proprietors, yet green spaces in China are usually managed by property 

10. 创智农园区位图
1. 创智农园平面图
12. 创智农园鸟睡
10. Location of KICG
11. Master plan of KICG
12. Aerial view of KICG

management companies at the lowest cost possible. Residents rarely are aware of their rights and responsibilities.

Therefore, community garden maintenance usually falls on the management company. "Collectively owned" spaces essentially become meaningless. ${ }^{[4]}$ Poor property maintenance coupled with aging communities has meant that some public residential spaces have been taken over as "private" garden spaces. Community empowerment, the process of community cohesion building, is one antidote.

The Herb Garden is in the central square of the third community, Anshan 4th Village, Yangpu District, Shanghai. The garden transformed the monotonous central green space of the old community into a public living room for the residents, and enhanced social interaction through added vegetation. Covering an area of only about 200 square meters, the Herb Garden provides a place of rest, education, and interaction for community members. It is a typical residential community garden designed and maintained by residents. The Herb Garden is divided into a children's playground, a spiral herb area, flower and groundcover area, and garbage area. The main varieties of plants include flowers, herbs and fruit trees, which have been added by residents overtime. The Herb Garden has two primary user groups. The first group includes community elders who share their love of flowers and experience gardening with each other. The other group is composed of a garden volunteer team consisting of 24 children. The young

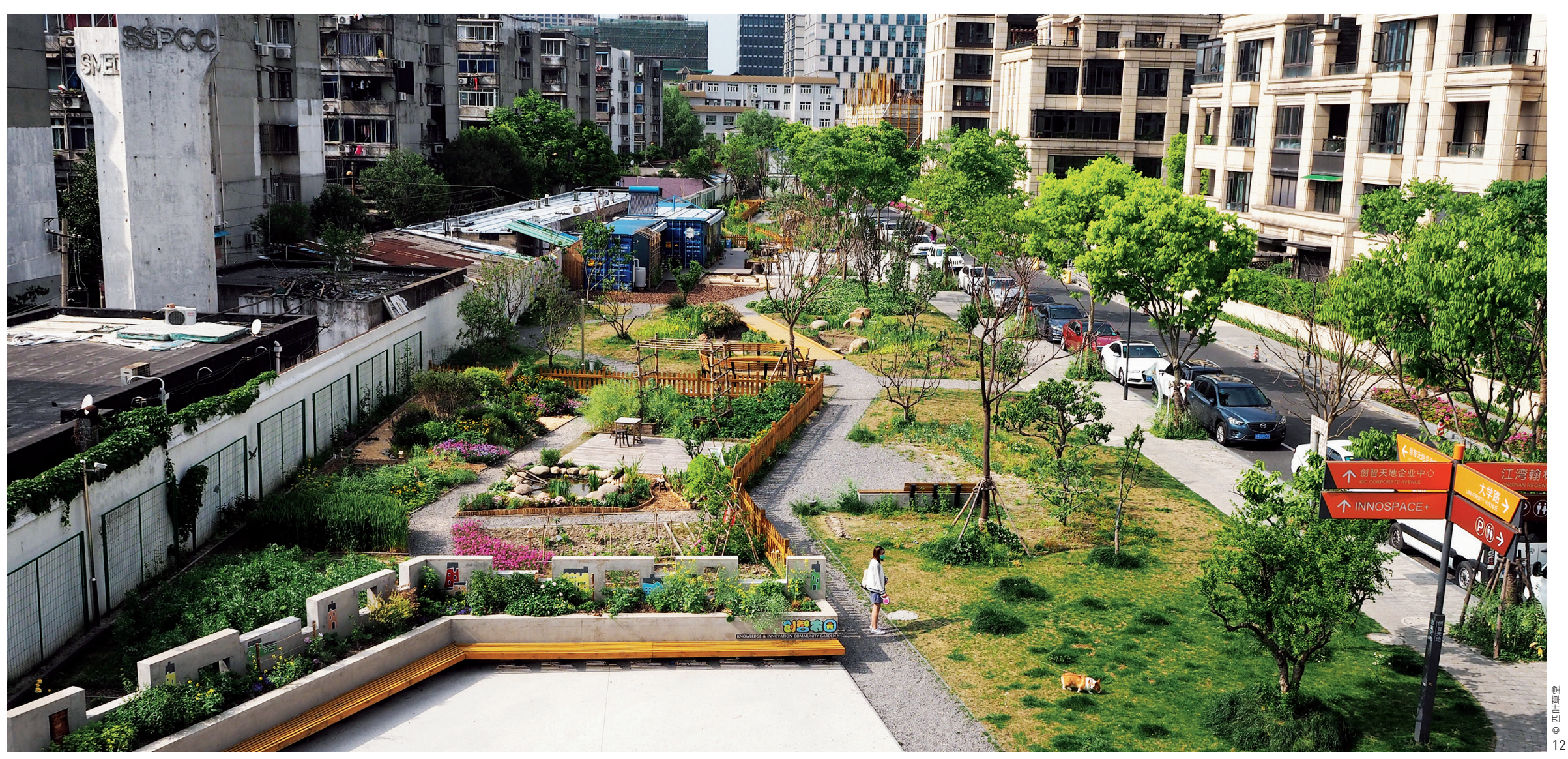




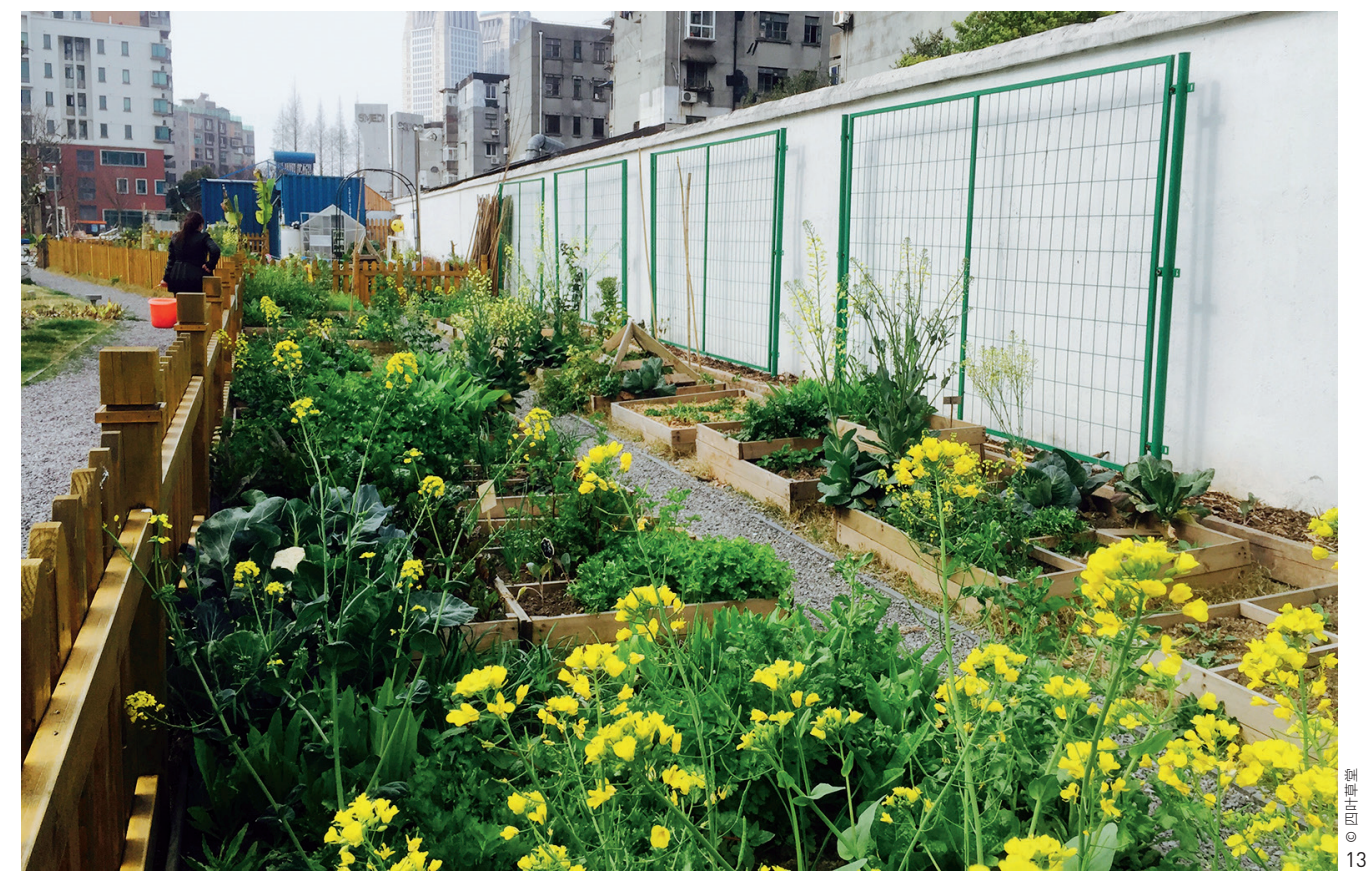

13. 创智农园中的一米菜园区
14. 创智农园中安静的阅读空间
15. 场地中的雨水收集设施
16. 蛏场堆肥塔
17. 社区居民参与收割水稻
13. Pocket gardens of KICG
14. Quiet reading space in KICG
15. Rainwater collecting
facilities
16. Worm tower for composting
17. Community residents
participating in harvesting

volunteer team works to set up shelves for planting, watering, and fertilizing the plants. They have also organized community activities including Mid-Autumn Riddles.

\section{Multi-Party Coordination: Knowledge \& Innovation Community Garden}

The key issue facing community garden construction is the need to clarify the relationship and operational mechanisms between stakeholders at the community level to maximize social resources and improve public participation ${ }^{[5]}$. In the process of operation and maintenance of Knowledge \& Innovation community Garden (KICG) , we have established a model for government, business, and social cooperation for community garden management.

KICG is located west of the Knowledge \& Innovation Park in the Wujiaochang Business District, Yangpu District,

Shanghai. It is a streetscape green area of about 2,000 square meters and surrounded by residential communities and industrial parks. Due to a municipal pipeline passing underground, the site has remained vacant. In 2016, the Yangpu Science and Technology Innovation Group and the Shui On Group decided to transform and re-use the site. Constructed and managed by the Shui On Group, with social organizations participating in daily operations, the site has become the first community garden in

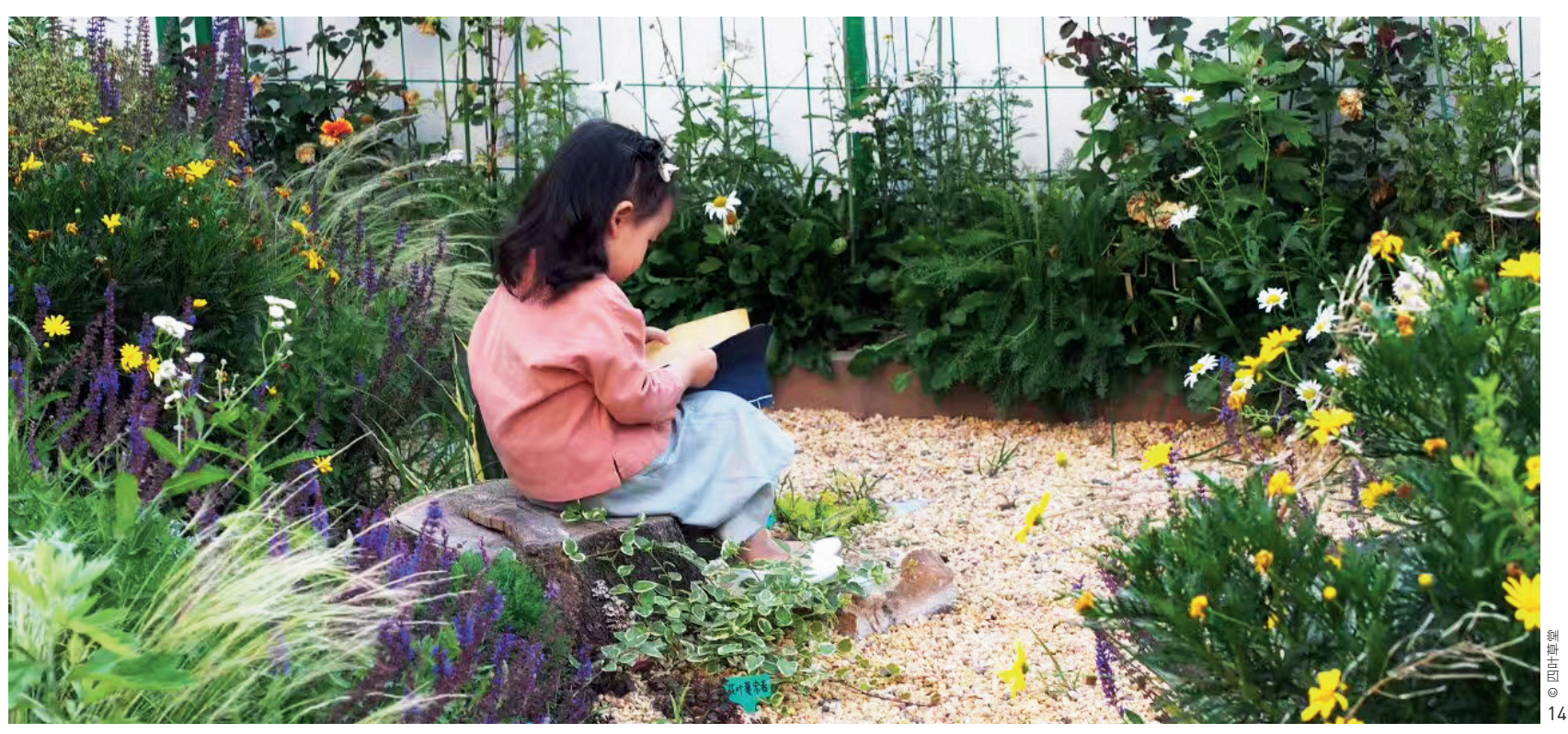


the open neighborhood of Shanghai.

The KICG site is divided into a mobile building area, a public social area, a onemeter vegetable garden area, and a public agricultural area. An outdoor school and community empowerment center were design goals of KICG. The design elements include science education features such as indoor seed library, DIY rainwater harvesting system, plant science identification system, indoor and outdoor public tables, and high-proportion edible plants.

The Shui On Group played a key role in the actual construction and management. From planning and design to construction, operation, and maintenance, the Shui On Group not only provided the main funds, but also ensured that the garden space was open and shared which may contribute to a high sense of social responsibility. At the management and maintenance level, the Shui On Group hired Clover Nature School to manage the daily operation and maintenance of the garden. As the bridge between the government, business and residents, Clover Nature School is responsible for the plantings, daily management, activity planning, and operations. The participating government departments have shown a certain degree of transparency, include the district government administrative departments, street offices and neighborhood committees. But we hope that in the future, the communities can self-organize maintenance responsibilities.

\section{Community Garden Network: Community Garden Promotion Association}

In 2016, the Shanghai Community Gardening Association (SCGA) was organized to bring together those working on promoting community engagement through community gardening. The SCGA aims to promote the development of Shanghai community gardens in a diversified and orderly manner by advancing the Shanghai 2,040 Food Forest Project (SFFP 2040), which aims to build 2,040 food forest landscapes in Shanghai by 2040 .

In January 2017, the SCGA started the Shanghai Community Garden Map, which allows communities to view the locations and introductions of other community gardens and to connect with other community garden users. The establishment of this community garden information database has also used crowd sourcing to attract public participation. The SCGA platform allows for updates on the latest activities and events related to community gardens.

\section{Conclusion}

Community gardens in terms of community green space, while diverse in terms of size and location, are always driven by community participation. Community gardens aim to mobilize communities to participate in social and public affairs, and we look forward to seeing more types of community gardens in cities around China. LAF

REFERENCES

(1] Mollison, B., \& Holmgren, D. (1978). Permaculture one : a erennial agriculture for human settlements. Tasmania: Tagari Publications.

[2] Mollison, B. (2014). Introduction to Permaculture. Zhenjiang: Jiangsu University Press.

[3] Hou, X. B. (2015]. Interactive landscape design - a case study of landscape transformation of Baoshan railway green space. Garden, (8), 46-50.

[4] Liu, Y. L. (2016). Community gardening - a new approach to free more micro urban space. Public Art, (4), 10-15.

[5] Liu, Y. L., Yin, K. L., Wei, M., \& Wang, Y. (2017). New approaches to community garden practices in high-density high-rise urban areas: a case study of Shanghai KIC garden. Shanghai Urban Planning, (2), 29-33.
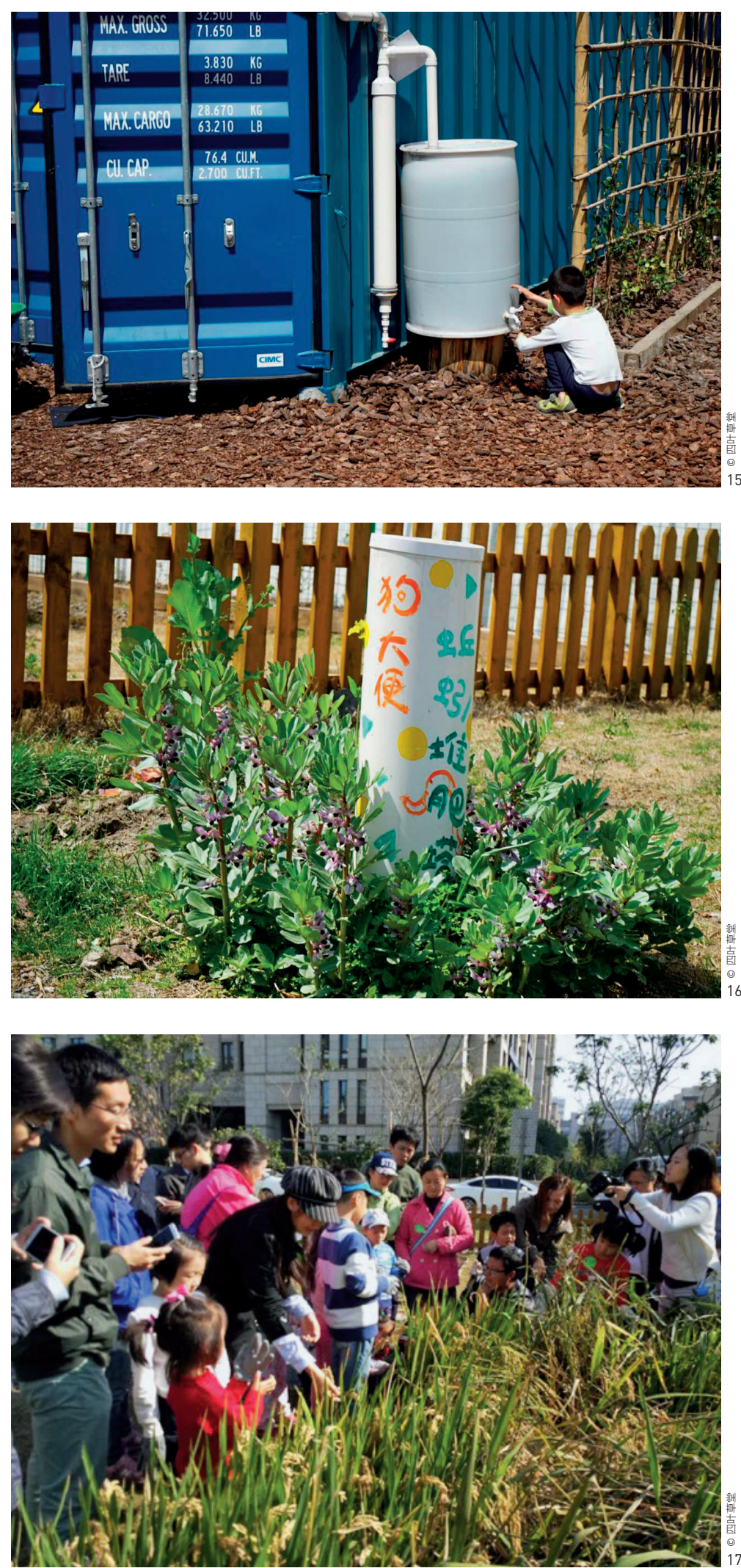